\title{
Federalism, Democracy and Foreign Direct Investment Inflows: Are They Complementary or Competing Concepts?
}

\author{
Diriba Adugna Tulu \\ Attorney General Office of Oromia Regional State, Addis Ababa, Ethiopia
}

\begin{abstract}
Least developed countries (LDCS) and developing countries desperately need foreign direct investment (FDI) for steady economic growth and sustainable development. Partly as a result of stiff competition due to globalization which brought about cross-border businesses through multi-national corporations (MNCs), those unfortunate economies are changing their policies and exerting their maximum potential to demonstrate themselves as favourable investment destinations in the eyes of MNCs. But, FDI comes to the host states only after thorough analysis of the benefits and costs because investors are motivated by making profits. Thus, obviously foreign direct investors opt for less risky investment. To achieve this, foreign direct investor's seriously look in whether the host state is a democratic state, adopted functioning federalism, etc so that they would easily forecast the political risks against their investments. The tendency is that, investors will not come and continue their operations if the political risks are high while they do where the political risks are lower. However, the conceptual relationships among democracy, federalism and FDI inflows are still very concerning issues all over the world. This paper clearly shows as federalism and FDI inflows on one hand; democracy and FDI inflows on the other side are complementary than competing concepts. Federalism, democracy and FDI inflows have been regarded as a mutually reinforcing couple by many scholars to date. Hence, democratic and federal countries attract higher levels of FDI through ensuring the lowering of political risks.
\end{abstract}

Keywords: - Foreign Direct Investment, Democracy, Federalism, MNCs.

DOI: $10.7176 / \mathrm{IAGS} / 68-02$

Publication date:July $31^{\text {st }} 2020$

\section{Introduction}

Unlike foreign portfolio investment which is an investment in stocks or bonds abroad, FDI is an investment in real operations such as capital expenditures on fixed assets. FDI is "an investment made to acquire lasting interest in enterprises operating outside of the economy of the investor"'(https://unctad.org). The lasting interest implies a long-term relationship between the direct investor and the enterprise and usually gives the direct investor an effective voice in the management of the enterprise. Moreover, according to World Bank, the most basic feature of FDI, which differentiates it from foreign portfolio investment, is that it is undertaken with the intention of exercising control over an enterprise (https://woldbank.org). Besides, OECD (2008a) defines a foreign direct investor as;

"an entity resident in one economy that has acquired, either directly or indirectly, at least $10 \%$ of the voting power of a corporation, or equivalent for an un incorporate enterprise, resident in another country".

States (especially the developing states and LDCs) need FDI for steady economic growth, sustainable and inclusive development, and tremendous exogenous benefits through transfer of efficient and effective managerial skills, transfer of technology, knowledge, and capital. While MNCs, as they are most known by their strategic behaviors (Madhu, 2009; Yang, 2007), are more likely to invest in countries with lower political risks. This is because investment implies a commitment of resources in the present for an uncertain return (pay-offs) in the future. Unlike commercial risk which is a natural part of doing business, political risks such as unforeseen policy changes have major implications for the viability of the investment. Also, investors prefer their projects to be immune from acrimonious intergovernmental squabbles and political interferences (Sharma, 2017).

On top of these, due to the increasing levels of globalization in the recent decades, nations have become more integrated. Globalization is not free from negative impacts albeit its benefits abound. Amongst the negative consequences of globalization, the most serious one is not only resulting in the stiff competition among states on the ability to attract FDI inflows; but also the competition for power and money. ${ }^{1}$ As a result, there is consensus within different literatures on globalization that, virtually every state today is engaged in policy manipulation designed to make their country more attractive in the eyes of MNCs (Rizvanov, 2014).

Although the study of federalism and democracy has become one of the most intensively studied areas in law, political science and other social sciences, no consensus has emerged on the linkages between democracy and FDI inflow in one hand and federalism and FDI inflows on the other hand. Some authors argue that those countries that

\footnotetext{
${ }^{1}$ It is obvious that globalization is more benefiting the Western Worlds (which have power or might, technology, and capital) at the expensive of LDCs and developing countries.
} 
are more democratic or that adopted federalism attracts larger FDI inflows. However, others authors argue the opposite. In this paper, I want to shows the conceptual interrelationship or complementarities among federalism, democracy and FDI inflows than competences.

The structure of this paper goes in the following manner. The paper begins with a look at the existing arguments on the relationship between investment and federalism. It then proceeds to examine the linkages between investment and democracy. This is followed by exploration of the relation between federalism and democracy on one hand and the additive effect of combining the two on attracting and retaining FDI inflows. The final part of the paper is devoted to conclusions.

\section{Federalism and Investment}

\subsection{Conceptual Clarification on Federalism}

Etymologically, the word "federalism" comes from the Latin, "foedus", meaning covenant, league, treaty, compact, contract, or bargain (Daniel and John, 1984).

Federalism is normative or ideological term just like capitalism, communism, or socialism while federation is the most common form of adopting federalism. Federalism is defined as "perpetuating both union and noncentralization at the same time" (Watts, 2007). It can also be defined as:

" a form of state structure by which power of a state is formally (constitutionally) divided among different orders of government, each of which is legally supreme over its own sphere- the federal institutions' (constituencies) clearly have their own fiscal and electoral base in relation to citizens and this is constitutionally entrenched" (Watts, 2007).

Federalism provides for an actual division of power between two or more nearly independent government each of which is against particularism and centralism authority over the same people.

From the above mentioned definitions, we can deduce that federalism is the direct opposite of unitarism. Thus, in federalism there are two equally strong needs and desires used as a base for adopting it; the need and desire to shoulder common interests jointly (self-rule for unity), and the need and the desire to shoulder domestic interests separately (self-rule for diversity).

Federalism is not mere decentralization but contractual non-centralization. Non-centralization is not the same as decentralization. This is because decentralization implies existence of a central authority and diffusion of power is a matter of grace, not right. Whereas, in a non-centralized political system, power is so diffused that it cannot be legitimately centralized or concentrated without breaking the structure and sprit of the constitution. In this regard, Watts (2007) has found that federalist countries (such as the US and Canada) constitutionally grant constituent units substantial autonomy over several major policy areas while many countries which have been decentralizing cannot be federal because decentralization is not firmly ingrained in the political structure. For decentralization to be firmly in the political structure, it needs non-centralization in the constitution. Besides, while policy decentralization ${ }^{1}$, can be achieved by fiat in unitary states, constitutionally established constituent units (in federalism) with the view of attaining non-centralization provide an extra and important protective barrier for policy decentralization.

At earlier times, federalism was considered as matter of structural or institutional arrangements (Kalu and Bing, 2016). The assumption was the introduction of a proper federal structure would create a functioning federal system. Many polities with federal structures were not truly federal in practice. For example, Eastern European federations, communist federations, etc. Again recently, federalism was confusedly seen as much a matter of process as of structure of federalism. Process is broadly defined to include socio-cultural and political dimension and application of federal principles in reality. Nevertheless, nowadays, federalism is the practice or style of governance (an institutionalized process) that aims towards the unification of entities (unity) and the reinforcement of a corresponding level of independence among territorial entities in a given political space (diversity), and thereby attains peace which is the ultimate value of equalizing unity and diversity (Kalu and Bing, 2016).

Many LDCs implement federalism and decentralization in order to gain credibility in the political arena and achieve greater efficiency in terms of economic performance (Rizvanov, 2014). This contributes for the attraction and retention of FDI inflows in the LDCs.

\subsection{The Basic Virtues of Federalism in Relation to FDI Inflows}

Federalism contributes for attracting and retaining FDI inflows by providing the following basic advantages.

First and foremost, federalism provides efficient and effective solutions because of closeness to the problem. In federalism, there is subsidiarity principle. This is a notion that higher political body should take up only those tasks that cannot be accomplished by lower political bodies themselves. This is because, as noted by Hayek (1945) and Rizvanov(2014), better spending decisions can be made on a local level as possible due to the fact that the

\footnotetext{
${ }^{1}$ It can be said that policy decentralization (having the effect of non-centralization) is the key to federalism's strong rights and economic performance.
} 
government located closer to the people possesses better information concerning the needs to those people than a more central and distant government would. Besides, federalism also ensures policy responsiveness by noncentralizing policy making and implementing. In this regard, it is reported that federalism is a construct mechanisms of policy making by diffusing it to as local level as possible, and thereby ensure both effectiveness and maximum representation (Rizvanov, 2014).

Secondly, federalism brings about additional level of checks and balances. This, in turn, contributes for dispersal of power and the prevention of tyranny, and thereby ensures favourable investment climate.

Thirdly, federalism enhances more political participation through local democracy. In a full-fledged federalism, there exist multiple levels of voting and representation which also contributes for investors' confidence to invest in the host state.

Fourthly, federalism brings about greater economy of scales- big internal market and big resources which are very crucial for foreign investors especially for resources-seeking and market-seeking FDI.

Fifthly, federalism contributes for creative competition for best practices (laboratory federalism) which in turn leads to "policy experimentation and innovation"(Inman, 2008). Constituent units (to which policies are decentralized constitutionally) fully act on the policies and complete each other through which they will come-up with best practices. Then, the best policy will be taken by other constituent units as part of experience-sharing. It is also a truism that as local governments are in control of smaller pool of resources, they can be used as "laboratories" for policy experimentation since failures are more likely to be localized and hence smaller in terms of damage (Rizvanov, 2014). In addition to this, local units in federalism are free to act as laboratories for experimentation and this paves the way for new and imaginative solutions to societal problems (Singh, 2005).

To sum up, the aggregate effect of the aforementioned virtues of federalism lowers political risks and instabilities in host states, ensures favourable investment climate, and boast investors' confidence, and thereby contributes for attracting and retaining FDI inflows.

\subsection{Arguments on the Relationship Between Federalism and FDI Inflows}

There are two contrasting views concerning the conceptual linkages between federalism and FDI. While, some authors argued that federalism can chills FDI inflows; many other authors argued that federalism does attracts and retains FDI inflows. The following essay takes a look at both sides of the argument.

\subsubsection{Federalism Chills FDI Inflows}

Federalism can exacerbate risks in creating multiple veto players (decision makers) (Rizvanov, 2014). In case the numbers of veto players are many, it is difficult to change a policy. It is also the case that foreign investors, who in their very business nature need to get one-stop-shop service, would face elongated bureaucracies in their admission and operation (Rizvanov, 2014). Federalism also increases bureaucratic hold up problems and lags (Kessing S, Kai A, and Christos K 2007; Rizvanov, 2014). ${ }^{1}$ These may affect foreign investors' interest and confidence to invest in the host state. It also results in termination of agreements by foreign investors. Thus, federalism chills the attraction and retention of FDI inflows.

Moreover, federalism promotes human rights and democracy ${ }^{2}$ which foreign investors do not favour. This is because flow of FDI in the LDCs and developing countries is aimed at resource-extraction with no or lower labor standards, minimal environmental standards, human rights standards, and generally "race-to the bottom" on these all standards. Thus, FDI fear the better protection of human rights and environmental standards in federalism against their aim to extract resources freely. In such a way that federalism chills FDI inflows.

\subsubsection{Federalism Attracts and Retains FDI Inflows}

Federalism ensures policy decentralization and thereby attracts and retains FDI inflows. Weingast (1995) found that federalism promotes FDI if it is based on the "Market-Preserving Federalism" having the following 5 (five) basic characteristic;

i. Two (levels) $)^{3}$ of governments rule the same land and people, each with a delineated scope of authority so that each [level] of government is autonomous on its own, well-defined sphere of political authority.

ii. Autonomy being institutionalized so as to make federalism restrictions self-enforcing. i.e. democracy.

iii. Sub-national governments with primary regulatory responsibility over the economy.

\footnotetext{
1 Where in a hypothetical example of a foreign investor wishing to finance a project in Germany was employed as;

"Investor who made the decision to build a plant in, say, Munich, has to deal with several governments: with the city government of Munich, with the district government in the district in which Munich is located, with the government of the state of Bavaria in which Munich is located, and with the federal government of Germany, as Munich also belongs to Germany".

${ }^{2}$ But this is true only for full-fledged federations like USA, Switzerland, Australia, and Canada; not for African and Latin American federations. 3 Here it is better to say "order" as the use of terms like "level" shows the existence of hierarchy or subordination between and among the federal and constituent governments that is not tolerable in federalism. This is because in federalism both the federal government and the constituent units derive their power from one and the same constitution. Thus, no one is subordinate to the other; all are equal acting within their spheres of powers.
} 
iv. Existence of common market.

v. Lower governments facing a hard budget constraint, that is, they have neither the ability to print money nor access to unlimited credits.

Hence, constituent state's autonomy short of the ability to print money, mint coins, and unlimited access to credit makes the political and economic competition among jurisdictions, and competition for attracting and retaining FDI inflows in particular.

Again, just like democracy, federalism lowers risks (Sharma, 2017) ${ }^{1}$, and thereby attracts and retains FDI inflows. It is also the case that federalism increases the number of veto points ( $\mathrm{Li}, 2006)$. This increases stability and consistency of policy, i.e. no volatile policy changes. Policy stability, in turn, is positively and directly related to greater investment by MNCs in the host states. Since corporations' major incentive is to increase profits, they are reasonably expected to and conform very well, to the behavior of strategically making both short and longterm choices in a future that is always uncertain. Accordingly, MNCs strongly prefer policy stability as it alleviates the risks of governments' reneging on their pledge or even downright expropriating multinationals' assets. Only through this that MNCs increase their expected benefits and future pay-offs. Hence, corporations care about policy stability (Rizvanov, 2014). ${ }^{2}$

Moreover, advocates from economics see federal governances as a means to efficient public and private sector performance, proponents from political science as a means to political participation and democratic stability, and legal scholars argue for federalism as a way to check central government powers and possible abuses of personal rights and liberties including federalism's ability to protect economic rights to own and allocate property and thereby enhances private sector economic performance(Inman, 2008). This contributes for attracting and retaining FDI inflows. It is also plausibly indicated that many countries including the highly centralized ones such as China, Norway and Sweden are now finding a federal style of governmental decision making a useful and acceptable means for implementing economic reforms (Inman, 2008).

It is better to notice that the argument which says federalism chills FDI does no weight much. This is because empirical study on India (federal state) Vs China (highly centralized state) has proved this. To that effect, Rizvanov (2014) has conducted an empirical study on the inflows of FDI over the 40 years period into these two countries which are roughly similar on many relevant political and economic characteristics, but which differ in terms of their position on federalism viz. India and China. While India is a highly developed federalist system, China is a very centralized one. Accordingly, the findings of the study disproved the conclusions reached by Kessing S, Kai A, and Christos K (2007)which say federalism chills FDI- India that follow a federal state is found to attract higher volumes of FDI inflows than China which is a centralized state (Rizvanov, 2014).

But, caution needs to be taken not to reach on hasty conclusion as regards the contribution of federalism towards attracting and retaining FDI inflows. This is to say that federalism, albeit it contributes to the valued outcome of government efficiency, does not guarantee for democracy and better investment climate so as to attain its role in attracting and retaining FDI because there may be federal dictatorship. Concerning this, Inman (2008) has shown that "federalism needs democracy; there is no evidence that adding policy decentralization or provinces to a dictatorship significantly improves a dictatorship's economic and rights performances."

\section{Investment and Democracy}

\subsection{Conceptualizing of Democracy}

Democracy originated many years ago in ancient Greece. The word democracy comes from two Greek words: "demos" meaning people and "kratos" meaning rule (Campbell, 2008). Or, in the memorable phrase of President Abraham Lincoln, democracy is government "of the people, by the people, and for the people (Sodaro, 2004).

For our purpose, we can define democracy as a form of government in which powers and responsibilities are exercised by all citizens directly or indirectly through their freely elected representatives.

But, democracy is more than just a set of specific government institutions; it rests upon a well understood group of values, attitudes, and practices.

The basic features of democracy, having their own contribution towards attracting and retaining FDI inflows are the following:-

$>$ Decentralization (and separation) of powers and civic responsibilities.

$>$ The principle of majority rule, which means that decisions are made by majority and have to be accepted

\footnotetext{
Wherein it has been indicated that:

"for understanding political risks literatures employed variety of factors, such as government interference, incomplete transactions leading to frequent changes in terms of agreement, political corruption, political events such as violence and terrorism, and political instability- for example, an unexpected charge in government leadership. Overall, political instability measured as the probability of a change of government, has been found to be negatively and significantly correlated with FDI".

2 Wherein it shown that the number of veto points should be directly related to the stability of polity, the higher is the number of veto points, the less volatile policy stability tends to be. Policy is much more volatile (likely to shift) if an agreement of only one decision makers is required, whereas it is much more likely to remain consistent if simultaneous agreement of several decision makers is required in order to change the status quo.
} 
by all, but minority rule, which means that decisions are made by majority, and have to be accepted by all, but minority viewpoints are respected and protected.

$>$ It guards against all-powerful central governments and decentralizes government to regional and local orders, understanding that all orders of government must be as accessible and responsive to the people as possible.

$>$ Ability to resolve disputes via non-violent, legitimate processes. Thus, better conflict management.

$>$ Rule of Law (OECD, 2015b); neither rule by law nor rule of men. The difference among these concepts is: in rule of law, the source of the law is the people themselves and the law is superior even on the law makers, in rule by law the people shall be governed by the law made by the governor without questioning its validity, while in rule of men, it is the governor who rules considering the general public as its own subjects.

$>$ Protect such basic human rights and freedoms as the right to participate fully in the political, economic, and cultural life of society.

$>$ Democracies conduct regular free and fair elections open to all citizens of voting age. In democracies, citizens and candidates are free to campaign against the government. There shall be effective choice .i.e., choice of electors is not limited to single party and the majority vote against the government in power leads to a change of government (Singh, 2005). A democratic constitution defines the rules of the game that politicians must play to win power and to use it (Myerson, 2006).

$>$ Citizens in a democracy have not only rights, but also the responsibility to participate in political systems.

$>$ Democratic societies are committed to the values of tolerance, cooperation, and compromise.

$>$ The performance of democracy should be evaluated by its effectiveness in deterring political leaders from corrupt abuse of power (Myerson, 2006). ).

$>$ Strong and independent judiciary free from executive interferences.

Generally, the above mentioned features of democracy make it a safe haven for FDI inflows by decreasing political risks and increasing policy stability which foreign investors seek in order to invest in host states.

\subsection{The Existing Arguments on the Relationship Between Democracy and FDI Inflows}

There are two views concerning the conceptual linkages between democracy and FDI. Some scholars like Yang (2007) argue that there is no systematic relationship between democracy and FDI. To be very specific on this argument, being a democracy does not help attract higher levels of FDI. However, many scholars argue that there exist a relationship between democracy and FDI. This latter view is further divided as to whether democracy chills or attracts FDI inflows.

\subsubsection{Democracy Chills FDI Inflows}

To start with this line of argument, scholar named Spar (1999) found that "first-generation FDI in developing countries up to the 1970s was driven largely by a search for raw materials (resource-seeking FDI)." This was backed by the findings of Busse (2003) who propounds that "during the 1970s a considerable share of FDI flowed to countries with repressive regimes." But, during the 1960s and 1970s, history tells us that states secured their independence from colonization. Then, the once colonized states started to consider foreign investments as economic colonization. Thus, independent states nationalized the investments of aliens under the guise of exercising one's permanent sovereignty over one's natural resources.

Furthermore, FDI favour autocracy for reasons such as its capacity to suppress labor demands, repress against protestors, and offer tax incentives to the advantage of MNCs (Madhu, 2009).

The firms in the extractive industries depended to a large extent on good relations with the government of the host country. From the host states, MNCs use natural resources; low cost labour; closeness to market for their products, robbing economic sovereignty and supporting repressive regimes (Busse, 2003).

Even the Amnesty International (2002), a non-governmental Organization, has reported that:

"Many MNCs operate in countries with repressive administrations where the rule of law is weak; where the independence of the judiciary is questionable; and where arbitrary arrest, detention, torture and extra-judicial executions occur. The government may ban free trade union activity and deny its freedom of association. Factory workers in plants from which companies source their products may be subject to inhuman and degrading working conditions."

Actually, however, the later studies (as shown in the $2^{\text {nd }}$ line of the argument below) tenably negated such assertion and empirically reported the importance of democracy for FDI inflows.

\subsubsection{Democracy Attracts and Retains FDI Inflows}

The empirical study conducted on US MNCs revealed "political stability, government policy commitment, and above all the favourable investment climate for attracting investors from US especially in manufacturing sector (Busse, 2003).

Harms and Ursprung (2002) also conducted study on 62 (sixty two) developing and emerging market economies and found that "MNCs are attracted by countries in which democracy is respected." This scholar 
reached on the conclusion that there is little evidence that weak democracies provide a haven for foreign investors.

Again, Jensen and McGillivray (2005) who found both democratic and federal countries attract higher levels of FDI through ensuring the lowering of political risks had come to exactly the opposite finding as Yang (2007), Spar (1999) and others. Also Jensen(2003) had reached on the same conclusion with his later finding concerning the role of democracy in attracting FDI- democracies ensure enforcement which promotes FDI inflows.

Li (2006) after conducting empirical study on 52(fifty two) developing countries from Asia, Latin America, also revealed that the reason why democracy attracts more FDI than other regimes is due to the strong property right protections available in it. This is to say owing to the existence of more institutions for better property rights protection for the private businesses in democratic countries, the risks of expropriation, contract repudiation, and government corruption are minimal.

Different incentive schemes and especially tax incentives were hugely used to attract FDI inflows. Amongst such incentive schemes are lowering the tax rates for MNCs so as to decrease costs of operating while increase their profits. However, Li (2006) has indicated that democratic countries offer lower levels of tax incentives while host countries that have weak property rights institutions and low policy credibility (autocratic governments) tend to offer generous tax incentives to attract foreign capital. High tax incentives for foreign investors in undemocratic states cause resentment among those who have to pay extra tax because of the revenue loss caused by incentive programs ((Li, 2006).

Moreover, democratic states offer more transparency in their economic and political affairs. Foreign investors may find avenues to pursue favorable policies in democracies and thereby lobby governments to their own preferred out comes (Li, 2006).

Again, democratic states have credibility in their dealings with foreigners. In case they negatively change their mind after contracting, they face audience or election costs. Besides, the higher number of veto players in the democratic system places constraints on policy changes, and thereby help attract FDI. Hence, democracy is the most important governance factor in attracting greater FDI inflows. Becoming a democracy makes the country a safe place to invest for MNCs because it lowers the political risks of nationalization and the enactment of unfavorable legislation (Madhu, 2009). Democracies also mitigate regulatory risks through transparency and public consultations while policy reforms are made and thereby ensure greater certainty for investors.

Furthermore, political instability, terrorism, strikes, and protests during Idi Amin's regimes as well as following the 2011 presidential election affected investment climate of Uganda for which different international organizations criticized Uganda (Riddervold, 2011). This also shows the positive role of democracy in attracting and retaining FDI inflows and the negative impact of undemocratic governance.

\section{Does Federalism contribute for the Democratic States in Attracting and Retaining FDI Inflows?}

As we have seen earlier, there is consensus in different literatures that MNC's decision to invest in a particular foreign country depends heavily on the level of political risk present in that nation. However, there are controversies among different scholars on the relation between democracy and federalism on one hand, and the cumulative effect of combining federalism and democracy on FDI inflows on the other hand.

For instance, the findings of Jensen and McGillivray (2005) indicated that federalism has a strong effect on the integrity of non-democratic countries. All else equal, federal non-democratic countries attract some of the highest levels of FDI. Accordingly, if a host state adopted federalism it secures higher inflow of FDI no matter that state is undemocratic.

However, later studies plausibly have found the crucial role of democracy in federalism to the extent that, let alone attracting FDI standing in itself, federalism could not exist or operate without democracies. For example, Singh (2005) concluded that:

"democracy may succeed both in unitary governments (such as France and England) while federalism cannot come into existence or existence or succeed its operation without democracy-no constitution such as of many Latin American countries or the former Soviet Union could establish a federal government for want of democracy."

Hence, democracy is a precondition for federalism, although in course of time, democracy starts getting sustenance and support from federalism. But, except the federal government cited by Singh (2005) as an example of democracies, ${ }^{1}$ it is not true that all federal governments are democratic. Nevertheless, in dealing with federalism and the role of democracy in federalism, Singh (2005) is only talking about the true (full-fledged) federalism than the pseudo-federalism.

Besides, federalism does not help non -democratic countries attract higher levels of FDI, nor does it improve upon democracy in attracting more FDI (Madhu, 2009). Democracy matters most and that federalism without democracy does not do anything to increase investors' confidence (Madhu, 2009). Without democracy, the federal structures do not hold as much weight; thus, investors do not have the confidence in these non-democratic federal

\footnotetext{
1 Wherein, US, Canada, Switzerland, and Australia are indicated as mature democracies.
} 
nations as they do in democratic countries (Madhu, 2009).

Additionally, in reflecting how federalism needs democracy, one scholar forwarded, there is no evidence that adding policy decentralization or provinces to a dictatorship significantly improves a dictatorship's economic or rights performance (Inman, 2008). Albeit, policy decentralization is the most important factor contributing to federalism's strong performance, such dependable performance of federalism is only observed in democracies (Inman, 2008). In spite of the fact that federalism can contribute to the valued outcome of government efficiency, it by no means guarantees such governmental efficiency (Inman, 2008).

The irony is, however, the additive effect of combining federalism and democracy on FDI inflows is minimal (Jensen and McGillivray, 2005)). But, it is an experimentally found truth that democratic countries are already regarded as trustworthy, so the additional credibility provided by federalism has little effect on FDI inflows (Madhu, 2009). Nevertheless, this does not mean that federalism does not contribute on democracy to attract and retain FDI inflows. i.e., as Singh (2005) has rightly put through time federalism can contribute for democracy. But, such contribution is not as such significant; rather only a little. And this contribution could take in the form of making policy stability and consistency which is a favourable climate for foreign investors.

\section{Concluding Remarks}

Many developing countries are actively seeking FDI because it they enjoy the transfer of skills, knowledge, and capital. While some studies report a positive relationship among democracy, federalism and FDI inflows, others show negative linkages among them. As mentioned above, a MNC's decision to invest in a particular foreign country depends heavily on the level of political risk present in that nation. Hence, democracy and federalism reduce unpredictable changes in the political environment. This in turn, attracts and retains FDI which is made after calculating the would-be profits in inherently uncertain future. Accordingly, as different experimental investigations dictated, countries with better democracy and federalism in their governance has attracted and retained better and productive FDI inflows within their economy though this may not work for extractive investments up until 1970s. Even currently, in some LDCs, few investments favour undemocratic governments to attain their exploitative, market and resource-seeking objectives. Democracy is a pre-condition for federalism but not the vice versa. Once a country is democratic state, it attains trust worthiness in investment climate and thus the additive (cumulative) effect of federalism on democracy as regards inflows of FDI is minimal, albeit, federalism contributes for sustenance of democracy and human rights protections through time. It is important to safely conclude that the concepts of democracy and FDI inflows on one hand; federalism and FDI inflows on the other side are complementary than competing. They have been regarded as mutually reinforcing concepts.

\section{References}

Books, Journal Articles and Unpublished Materials

1. Amnesty International (2002)."Business and Human Rights: Geography of Risk", London: Amnesty International and Prince of Wales International Business Leaders Forum.

2. Busse, M. (2003). "Democracy and FDI", HWWA, Discussion Paper 220, ISSN 1616-4814.

3. Campbell, D. (2008). "The Basic Concept for the Democracy Ranking of the Quality of Democracy" Vienna: Democracy Ranking.

4. Daniel, E and John, K. (1984). "The Covenant Connection: Federal Theology and the Origins of Modern Politics" Lanham, MD: Center for the Study of Federalism and University Press of America) for a more comprehensive treatment of the federal idea as essentially covenantal.

5. Harms, P., and Ursprung, H.W.(2002). "Do Civil and Political Repression really boost Foreign Direct Investments?" Economic Inquiry, 40(4), 651-663.

6. Hayek, F. (1945). "The Use of Knowledge in Society", American Economic Review 4(35): 519-530.

7. Inman, R. (2008). "Federalism's Values and the Value of Federalism", Working Paper 13735, National Bureau of Economic Research, Massachusetts Avenue Cambridge.

8. Jensen. N. (2003). "Democratic Governance and Multinational Corporations: The Political Economy of Foreign Investment", International Organization, 57(3), Pp. 587-616.

9. Jensen, N. and McGillivray. (2005). "Federal Institutions and Multinational Investors: Federalism, Government Credibility, and Foreign Direct Investment", International Interactions, 31, Pp. 303-325.

10. Kalu, O. and Bing, D. (2016). "Implication of Federalism in 'Federalism' Related Political Institutions: A Conceptual Analysis", in Perspectives on Federalism, 8(3), Pp. 45-68.

11. Kessing S, Kai A, and Christos K (2007). "Foreign Direct Investment and the Dark Side of Decentralization." Economic Policy 22(49): 5-70.

12. Li, Quan.(2006). "Democracy, Autocracy, and Tax Incentives to Foreign Direct Investors", in the Journal of Politics, 68(1), the Pennsylvania State University.

13. Madhu, A. (2009). “Federalism's Impact on Foreign Direct Investment Inflows, in Wharton Research Scholars Journal, University of Pennsylvania. 
14. Myerson, R. (2006). "Federalism and Incentives for Success of Democracy", in Quarterly Journal of Political Science, University of Chicago, ISSN 1554-0626.

15. OECD. (2008a). "Benchmark Definition of Foreign Direct Investment", Paris.

16. OECD. (2015b). Policy Framework for Investment”, OECD Publishing, Paris.

17. Riddervold, S. (2011). "The Effects of Foreign Direct Investment on the Ugandan Economy", Master's Thesis submitted to University of Agder, Faculty of Economics and Social Sciences, Depaartment of Development Studies.

18. Rizvanov, F. (2014). "Less Risky Investment? The Impact of Federalism on the Inflow of Foreign Direct Investment", A Thesis Presented to the Faculty of the Graduate School at the University of Missouri-Columbia In Partial Fulfillment of the Requirements for the Degree of Master of Arts in Political Science, (Published).

19. Sharma, K. (2017). "Federalism and Foreign Direct Investment: How Political Affiliation Dtermines the Spatial Distribution of FDI- Evidence from India", GIGA Working Papers, No. 307, German Institute of Global and Area Studies (GIGA), Hamburg.

20. Singh, M. (2005). "Federalism, Democracy, and Human Rights: Some Reflections with Special Reference to India', Journal of the Indian Law Institute Vol. 47, No. 4 (October-December 2005), Pp. 429-446.

21. Sodar, M. (2004). “Comparative Politics: A Global Introduction”, New York: Mc Graw Hill.

22. Spar, D. (1999). "Foreign Investment and Human Rights", Challenge, 42(1), Pp.55-80.

23. Watts, R.(2007a). "The Federal Idea and Its Contemporary Relevance", Institute of Intergovernmental Relations Queen's University, Kingston, Canada.

24. Watts, R. (2008b). “Comparing Federal Systems”, McGill-Queen's University Press, Kingston, Ont.

25. Weingast, R. (1995). "The Economic Role of Political Institutions: Market Preserving Federalism and Economic Development", in Journal of Law, Economics, and Organization, 11(1).

26. Yang, B. (2007). "Autocracy, Democracy, and FDI Inflows to the Developing Countries", International Economic Journal, 21(3), Pp. 419-439.

\section{Internet Sources}

1. Retrieved from https://unctad.org.

2. Retrieved from https://woldbank.org. 